[論 文]

UDC : 624. 042. $7: 620.1$
Journal of Structural and Construction Engineering (Transactions of AIJ) No. 401, July, 1989
旦本建築学会構造系論文報告集

第4 013 号. 1989 年 7 月

\title{
PART 4 : CONTROL OF EXPERIMENTAL ERROR GROWTH IN PSEUDO DYNAMIC TESTING
}

\author{
(Stability and Accuracy Behavior of Pseudo Dynamic Response)
}

\author{
by MASAYOSHI NAKASHIMA* and HIROTO KATO**, \\ Members of A.I. J.
}

\section{Introduction}

The pseudo dynamic (PSD) test (also referred to as the on-line computer test control method) is a combined experiment and numerical analysis that simulates the earthquake response behavior of structural systems with respect to the time domain. Since devised by Takanashi et al. (Ref. 1), this test has been employed by many researchers in both Japan and overseas (Refs. 2, 3). Through previous applications of the. PSD test, it has been disclosed that the PSD response is very sensitive to the performance of the hardware employed and often distorted if the hardware is not sufficient in controlling the load applying actuators and measuring the displacements and reactional forces. This distortion in response has been designated as the experimental (response) error. The writers examined the sources that would deteriorate the PSD response and their effects on the response (Ref.4). The examinations indicated that; $(1)$ the displacement error (defined as the displacement commanded minus the displacement achieved after the actuator motion) has the most significant effect on the PSD response; (2) the displacement error tends to show "undershoot" (here, the undershoot is a condition in which the displacement increment achieved after the actuator motion is smaller in its absolute value than the displacement increment commanded); and ( 3 ) the displacement error has a nature of promoting the highest mode vibration if the PSD test is applied to a multiple degree of freedom (MDOF) system. This paper is an extension of Ref. 4 and presents analytical examinations for quantifying the characteristics of the displacement error. This paper also proposes procedures to suppress the growth of the experimental error.

\section{Effect of Displacement Error on PSD Response}

The experimental error can be regarded as the response of the system against the error force, and, under the displacement error condition, this error force is given as the displacement error times the stiffness of the system. For a linear-elastic single degree of freedom (SDOF) system, the equation of motion that includes the displacement error effect can be formulated as :

$$
m \ddot{x}(i \Delta t)+c \dot{x}(i \Delta t)+k x(i \Delta t)=-m \ddot{x}_{g}(i \Delta t)+k d x(i \Delta t)
$$

where, $m, c$, and $k$ are the mass, viscous damping, and stiffness; $\ddot{x}_{g}$ the ground acceleration ; $d x$ the displacement error; $\Delta t$ the integration time interval; and $i$ denotes that the equation belongs to the $i$-th step computation.

2.1 Effect of Random Displacement Error

As indicated in Ref. 4, displacement errors scattered randomly if the allowable error (specified prior to the test) was set to be very small. Shing and Mahin (Ref.5) conducted a comprehensive study on the characteristics of experimental errors, and, here, referring to their findings, effects of random displacement errors are discussed. If the viscous damping is taken zero and further the acceleration term is neglected (i. e. the error force only), the displacement obtained from Equation 1 is:

$$
x(i d t)=\sum_{n=0}^{i-1} A \cdot \sin \bar{\omega}(i-n) \Delta t \cdot d x(n \Delta t)
$$

where $A=\omega \Delta t / \sqrt{1-(\omega \Delta t)^{2} / 4}$

\footnotetext{
* Associate Prolessor, Kobe University

** Research Engineer, Building Research Institute, Ministry of Construction (Manuscript received February 9, 1989 : Paper Accepted May 8, 1989)
} 
where $\omega$ is $\sqrt{k / m}$, and $\bar{\omega}$ the numerical natural circular frequency of the system. For details of $\bar{\omega}$, see Ref. 6 . Let us suppose that $d x$ follows the Gaussian distribution with the mean of zero and the standard deviation of $\sigma_{e}$ and is uncorrelated with respect to the time. By some algebraic work into Equation 2, the mean of the response is also found zero, and its standard deviation, $\sigma_{r}$, is :

$$
\sigma_{r}=A \cdot \sigma_{e} \cdot \sqrt{\sum_{n=0}^{i-1}\left(\sin ^{2}(i-n) \bar{\omega} \Delta t\right)}
$$

The time versus standard deviation relationship obtained from Equation 3 is plotted in Fig. 1, in which the abscissa and ordinate are normalized respectively by the natural period of the system and the standard deviation of the displacement error. To be remarked in this figure is that the experimental error (the ordinate) is more pronounced with the increase of the integration time interval, and this is the key to explain the reason why, in an MDOF system, random displacemient errors tend to promote the response corresponding to the highest mode. If, in an MDOF system, random displacement errors are assumed to be uncorrelated with respect to the degree, each vibrational mode (after modal decoupling) also sustains random displacement errors. Since the relative integration time interval (expressed as $\omega \Delta t$ ) is largest in the highest mode, the vibration of this mode is likely to be most promoted.

\section{2 Characteristics of Undershoot}

Although displacement errors were found randomly scattered if we set the allowable error very small, it is by no means an easy task unless the structure tested is significantly more flexible than the loading system. (Here, the stiffness of the loading system should be expressed as the accuracy of the load applying actuators in positioning the structure. ) In most cases, the undershoot prevails in the displacement error mechanism. If a constant undershoot $(\delta)$ is included in a PSD test of a linear-elastic SDOF system, its response can be obtained by solving Equation 1 with $d x$ as $\delta$ (Here, $\delta$ is taken positive when the displacement is ascending and negative when descending). Even if the

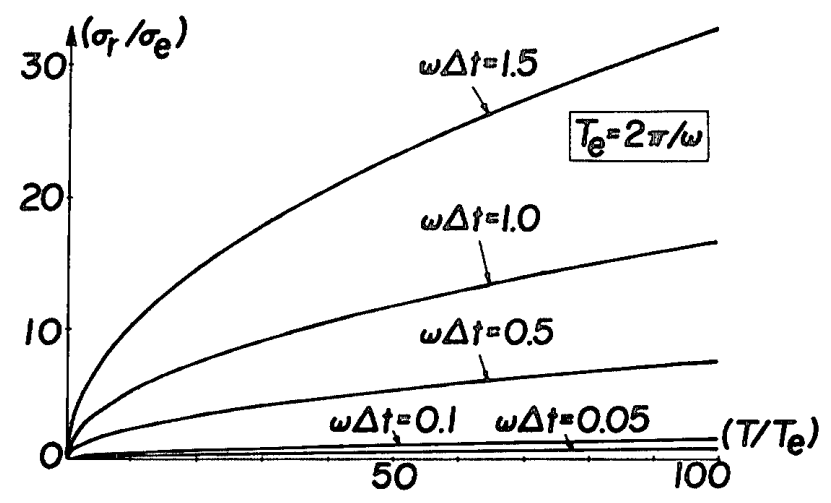

Fig. 1 Relationship Between Time and Response Error Caused by Random Displacement Errors

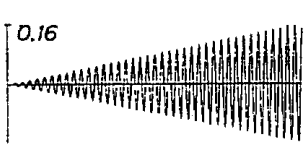

(a) Viscous Damping Ratio $=0.0$

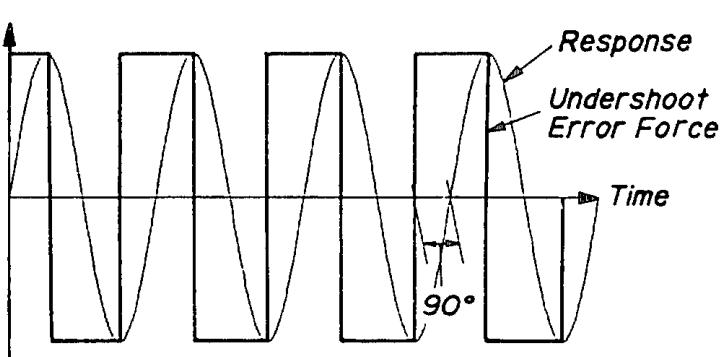

(c) Steady State Displacement Response and Undershoot Error Force

Fig. 2 Response of SDOF System Subjected to Undershoot $(\omega=50 \mathrm{rad} . / \mathrm{sec}: \delta=0.001 \mathrm{~mm})$
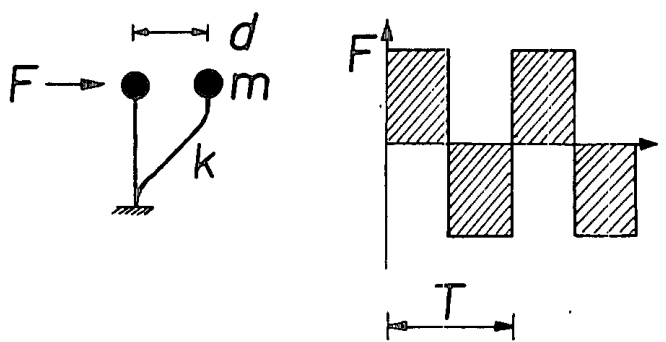

(a) SDOF System Subject to Periodic: Rectangular Force

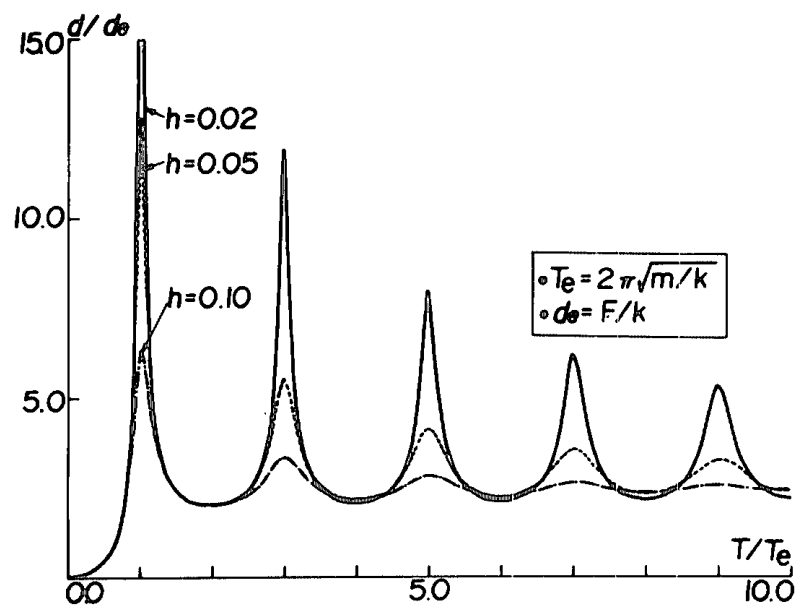

(b) Displacement Amplitude of SDOF System in Steady State ( $h=$ Viscous Damping Ratio)

Fig. 3 Response of SDOF System Subjected to Periodic Rectangular Force 
ground acceleration is taken zero, the response still diverges as shown in Fig. 2(a) if the viscous damping is zero. With nonzero viscous damping, the response falls into a steady state (Fig. 2(b)). The relationship between the steady state response and the error force (caused by the undershoot) is shown in Fig. 2(c). Two remarks should be given from this figure. First, the error force is a periodic rectangular force and lagged by 90 degrees in phase angle from the response. Second, the period of the response equals the natural period of the system; it is true because, a phase lag by 90 degrees between a sinusoidal external force and its response can be achieved only when the system is in the resonant condition. (The periodic rectangular force can be approximated reasonably as a sinusoidal force having the same frequency. ) Next, let us suppose the response when the SDOF system is subjected to a periodic rectangular force (Fig. 3(a)). This force is to represent the error force caused by the undershoot. The amplitude of this system in the steady state is plotted in Fig. 3(b) against the period of the rectangular force and for various viscous damping ratios. In this figure, the abscissa and ordinate are normalized respectively by the natural period of the system and its static displacement. Figure $3(\mathrm{~b})$ indicates that, in the range where the period of the rectangular force is smaller than the natural period of the system : i. e. the range given by $T / T_{e}$ less than 1.0 , the response decreases drastically with the decrease in $T / T_{e}$. In the range where $T / T_{e}$ greater than 1.0 , the response is never negligible and promoted significantly when the period of the rectangular force equals an odd number times the natural period of the system. Based on the findings obtained in Figs. 2 and 3, finally considered is an MDOF system that undertakes undershoot. Here, the magnitude of undershoot is assumed constant with respect to both the time and degree. Supposed that, in a steady state, the system responds in its highest mode, the error force applied to each mode (after modal decoupling) is a periodic rectangular force whose period equals the natural period of the highest mode. It means that, in Fig. $3(\mathrm{~b}), T / T_{e}$ is positioned at 1.0 for the highest mode and less than 1.0 for all of the lower modes (because of larger $T_{e}$ 's in these modes). Since the response is made minimal in the region where $T / T_{e}$ is smaller than 1.0, these lower modes are most likely in inaction, and, therefore, little contradiction arises as to assuming that the MDOF system responds with its highest mode.

2. 3 Magnitude of Response Error. Caused by Undershoot

The magnitude of the experimental error caused by the undershoot can be estimated through energy consideration. In a linear-elastic SDOF system sustaining a constant magnitude of undershoot, considered is a half cycle from the maximum to minimum displacements as shown in Fig. 4, in which the absolute values of these displacements are $x_{1}$ and $x_{2}$, and $x_{1}<x_{2}$, because the response grows with time. The energy added to the system during this half cycle is given as:

$$
d E=1 / 2 \cdot k \cdot x_{2}^{2}-1 / 2 \cdot k \cdot x_{1}^{2}
$$

This energy is to equal the energy generated by the undershoot $(d E a)$ minus the energy dissipated by the viscous damping $(d E v)$ in this half cycle. They can be expressed as:

$$
\begin{aligned}
& d E a=\delta \cdot k \cdot\left(x_{1}+x_{2}\right) \cdots \ldots \ldots . \\
& d E v=\pi \cdot c \cdot \omega \cdot\left(x_{1}+x_{2}\right)^{2} / 8
\end{aligned}
$$

The energy balance requires:

$$
d E=d E a-d E v
$$

Substituting Equations 4 to 6 into Equation 7, we obtain for the relationship between $x_{1}$ and $x_{2}$ as:

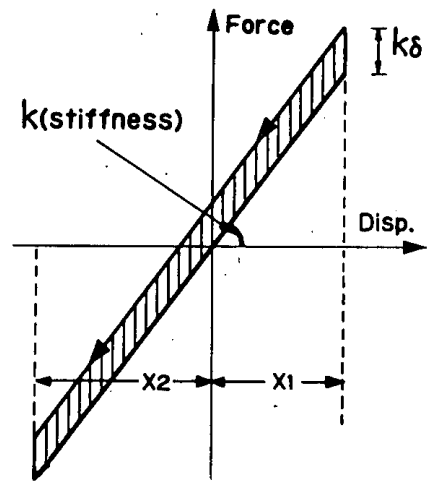

Fig. 4 Growth in Displacement Amplitude by Undershoot

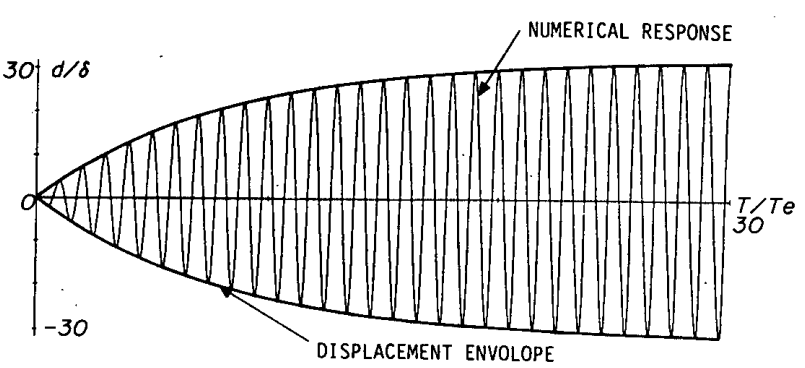

( $d$ = Displacement Ampl 1 tude)

Fig. 5 Growth of Response Error Caused by Undershoot $(h=0.02)$ 


$$
x_{2} / \delta=\left(2+(1-\pi \cdot h / 2) \cdot x_{1} / \delta\right) /(1+\pi \cdot h / 2)
$$

in which $2 h \omega=c / m$. This recursive equation specifies the growth of the experimental error caused by the undershoot. (Remember that the time difference between $x_{1}$ and $x_{2}$ is half the natural period of the system.) Figure 5 shows an numerical response of an SDOF system under a constant undershoot (obtained by the direct time integration) and also plots the envelopes given by Equation 8, which indeed traces the peak values of the numerical response. Using Equation 8, we can estimate the growth of the experimental error with time, and it is shown in Fig. 6 for various viscous damping ratios. Further, by equating $x_{2}$ with $x_{1}$ in Equation 8, we obtain for the amplitude in the steady state $(d)$ :

$$
d=2 \cdot \delta /(\pi \cdot h)
$$

Comparing Fig. 6 with Fig. 1, we find that the undershoot promotes the experimental error more significantly than the random displacement error as long as the system is lightly damped and the integration time interval is kept reasonably small. Using the concept of modal analysis and particularly looking into the highest mode, we can also estimate the growth of the experimental error in MDOF systems.

\subsection{Comments on Error Growth by Displacement Errors}

Two comments should be given about the value of the above examinations. First, the magnitude of displacement errors (either random or undershoot) was assumed constant with respect to the time. but, in real PSD tests, they should vary with the time as well as the degree. Choosing, for the magnitude of the displacement error, one of the largest values expected in the test, we can estimate an upper bound for the experimental error. Second, it was assumed that the system behaves linear-elastically. When the system starts behaving inelastically, it normally loses the stiffness. This loss in stiffness decreases the magnitude of the error force and accordingly the growth of the experimental error. It should be true, because the error force is given as the product of the displacement error and the stiffness. Thus, estimate based on the elastic properties also gives an upper bound for the experimental error.

\section{Control of Experimental Error Growth in PSD Test}

The most ideal.way to reduce the experimental error is to improve the performance of the hardware employed in the test and reduce the displacement error as much as possible. However, we always have to deal with reality and accept some imperfectness in our hardware. Here, consideration is given to how we can minimize the experimental error using a PSD test system that inevitably includes displacement errors.

\subsection{Effect of Viscous Damping on Experimental Error Growth}

Since, as shown in Fig. 6, the magnitude of the experimental error becomes smaller with the increase in the viscous damping ratio, we may be able to reduce the experimental error by adding artificially high viscous damping into the equations of motion. In fact, in some of the previous applications (Refs. 7, 8), high viscous damping ratios were introduced for higher modes in order to suppress possible promotion of these modes. However, such procedure involves two drawbacks. As, in this procedure, the damping matrix is constructed in reference to the initial elastic stiffnesses, this matrix no longer guarantee the desired viscous damping ratios once the system starts behaving inelastically. The larger are the damping ratios assigned originally for the higher modes, the more significantly

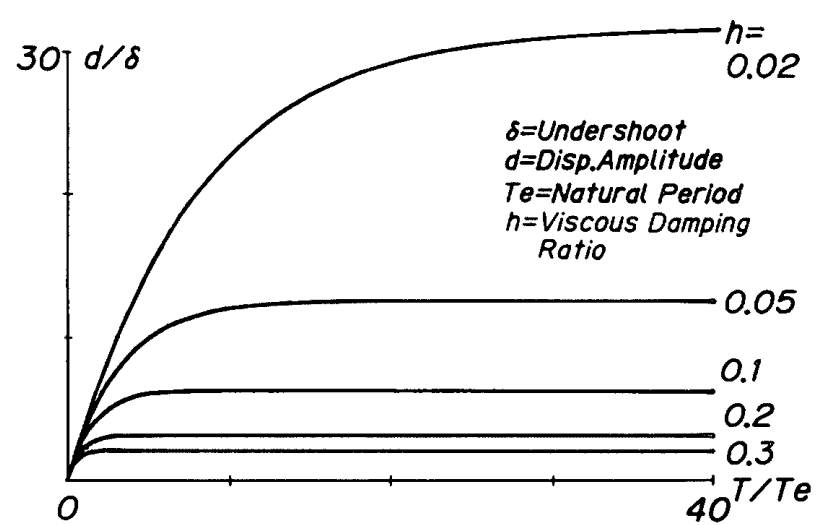

Fig. 6. Relationship Between Time and Response Error Caused by Undershoot
Table 1 Designation and Test Conditions for PSD Tests with I-Modification

\begin{tabular}{|l|c|c|c|}
\hline $\begin{array}{c}\text { Designation } \\
\text { of Test }\end{array}$ & Loading Condition & $\begin{array}{c}\text { Error } \\
\text { Bound } \\
\text { (mm) }\end{array}$ & I-liodification \\
\hline EQ02I & Elastic Response & 0.02 & No \\
EQ10I & Elastic Response & 0.10 & No \\
EQ02IM & Elastic Response & 0.02 & Yes \\
EQ10IM & Elastic Response & 0.10 & Yes \\
EQ10PIM & Inelastic Response & 0.10 & Yes \\
\hline * As input accelerations, part of the accelerations \\
recorded at Tohoku Univ. during the 1978 Miyagi-oki \\
Earthquake, with the maximum acceleration scaled. \\
\hline
\end{tabular}


affected are the effective viscous damping ratios in the important lower modes during the inelastic response. Second, as shown in Fig. 4, the essence of the undershoot is negative Coulomb damping, in which the energy created per a cycle of loading is proportional to the displacement amplitude (if the magnitude of the undershoot is taken constant). On the other hand, the velocity proportional viscous damping dissipates energy in proportion to the square of the displacement amplitude. If the system responds steadily with a constant amplitude, it is possible to allocate a unique viscous damping ratio with which the energy added by the undershoot can be canceled, but, in nonstationary responses such as those induced by earthquake loading, no such damping ratio can be assigned. Although adjusting the viscous damping term is seemingly one of the handiest ways to suppress the experimental error, it is believed to make us unduly difficult to evaluate the viscous damping effect on the response obtained.

\subsection{Algorithms to Suppress Experimental Error Growth}

As a means to suppress the experimental error more effectively than adjusting viscous damping, an algorithm was devised. This algorithm had its basis on our previous findings regarding the characteristics of experimental errors, i. e. that the error source is clearly defined as the displacement error and can be measured accurately but that the error still occurs because of insufficiency of the load applying actuators in positioning the test structure at the exact target position. In the algorithm devised, the actuator forces measured by load cells were modified, and the modified forces were used in place of the measured forces for solving the equations of motion. The modification procedure adopted was:

$$
\bar{f}\}=\{f\}+[k]\left\{x_{c}-x_{m}\right\}
$$

Here, $\{f\}$ and $\{\bar{f}\}$ are the measured and modified force vectors and, [k] the stiffness matrix, for which the initially estimated (elastic) stiffness matrix was employed. Further, $\left\{x_{c}\right\}$ and $\left\{x_{m}\right\}$ are the computed and measured displacement vectors. As long as the system responds elastically, in this algorithm (designated as I-Modification), the modified forces should equal the reactional forces corresponding to the exact target position. To evaluate the effectiveness of this algorithm, a steel braced frame tested previously (Fig. 4 of Ref. 4) was tested again, but with a new set of braces. Table 1 summarizes a total of five tests conducted in this test program and their test conditions. The results of Tests : EQ02I, EQ10I, EQ02IM, EQ10IM (in which the structure behaved elastically) are shown in Figs. 7 to 10, together with the responses obtained numerically. In Test EQ02I, the response did not diverge, but the second mode vibration was more promoted in the experimental response, whereas the response of Test EQ10I diverged within a very short period of time. On the other hand, the results with I-Modification (i.e. Tests EQ02IM
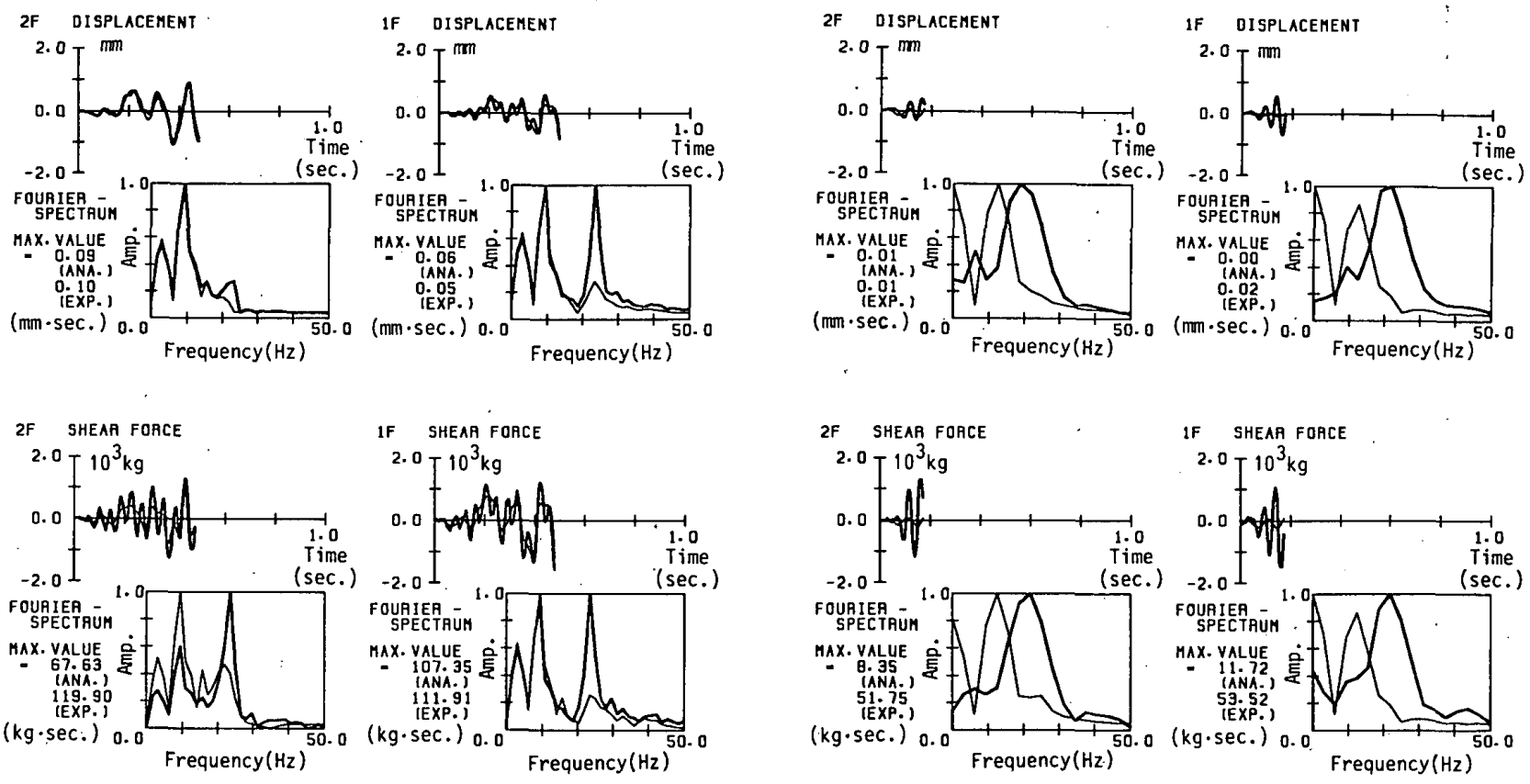

Fig. 7 Time Histories and Fourier Spectra Obtained in Test EQ02I
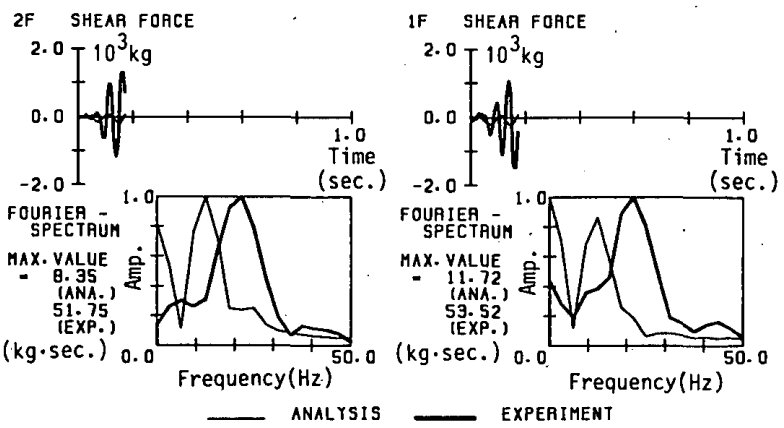

Fig. 8 Time Histories and Fourier Spectra Obtained in Test EQ10I 

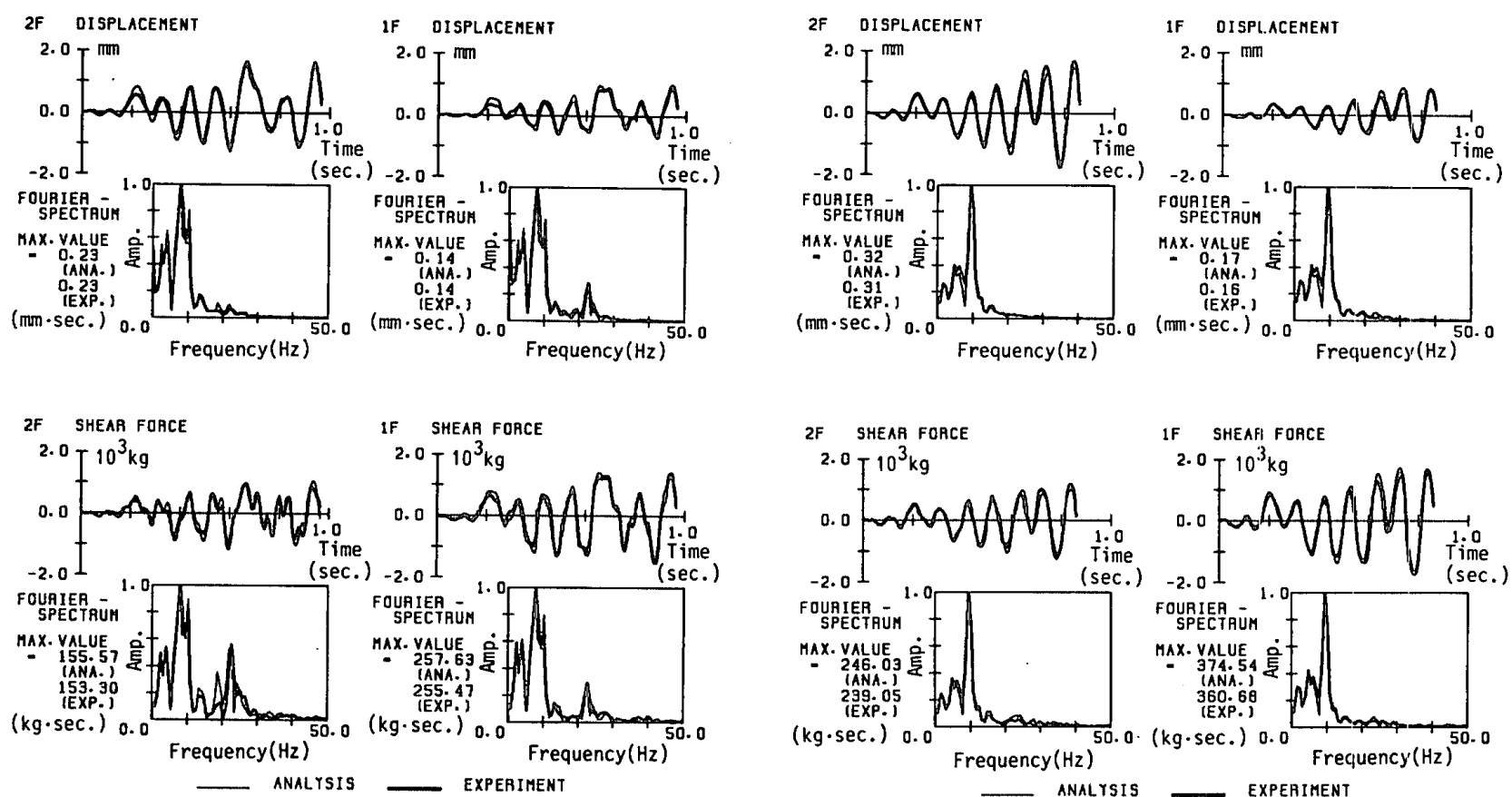

Fig. 9 Time Histories and Fourier Spectra Obtained in Test EQ02IM

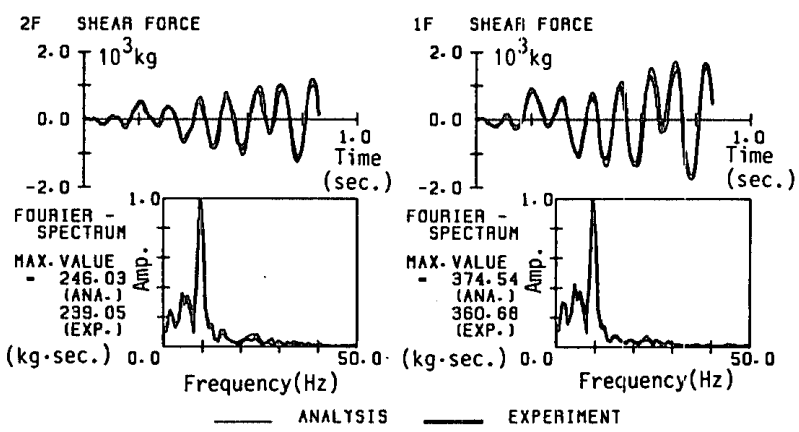

Fig. 10 Time Histories and Fourier Spectra Obtained in Test EQ10IM

and EQ10IM) did not show any sign of diverging behavior and closely matched the numerical responses, demonstrating the validity of this algorithm. Figure 11 shows the responses obtained form Test EQ10PIM (in which the structure behaved inelastically), together with the responses obtained numerically. In the numerical analysis, the restoring force behavior was simulated by a combined Ramberg-Osgood and slip model, and the coefficients included in this model were determined using the technique of system identification. See Ref. 9 for this technique.


Fig. 11 Time Histories and Fourier Spectra Obtained in Test EQ10PIM

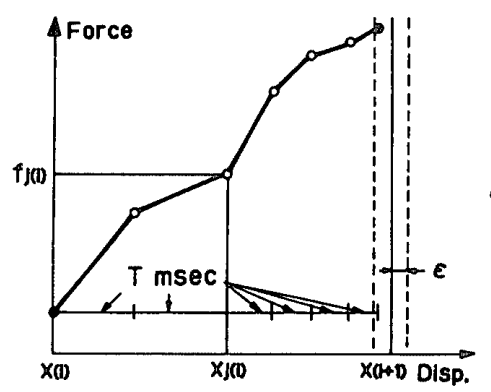

(a) Measurement of Restoring Forces

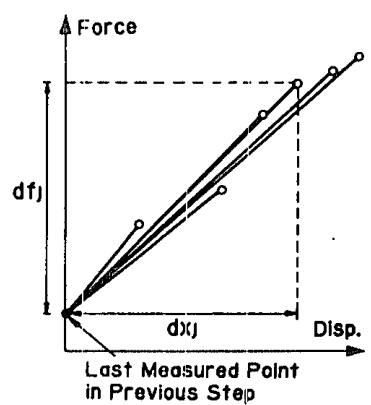

(b) Estimate of Tangent Stiffness

Fig. 12 Procedure to Estimate Tangent Stiffness in T-Modification

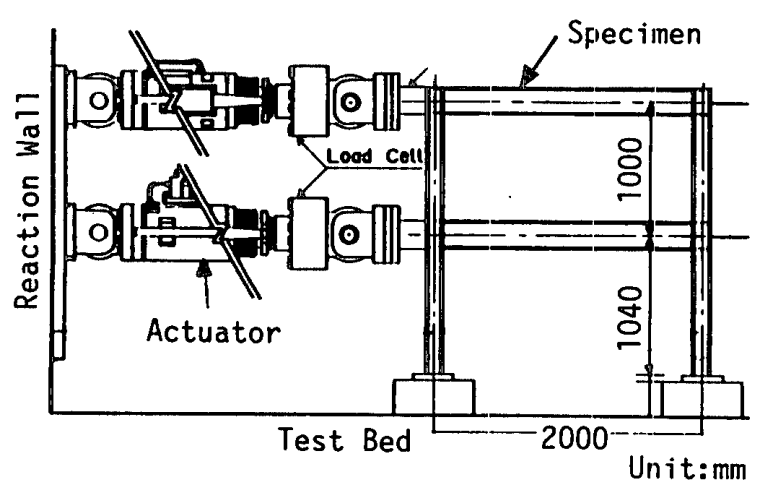

Fig. 13 Test Specimen and Setup Used in PSD Tests with T-Modification 
Figure 11 indicates that the experimental responses were close to the numerical responses, again indicating the effectiveness of the proposed algorithm. One may question why this algorithm provided an accurate result, because the stiffness properties should have changed during the inelastic response, while the modification was still based upon the initial stiffnesses. It was speculated that, during the inelastic response, energy dissipated by the hysteresis of the structure completely overshadowed possible errors induced by incorrect estimation of the modified forces.

To incorporate more directly the change in stiffness during the inelastic response into the force modification procedure, another algorithm, designated as T-Modification, was also devised. In this algorithm, for the stiffness

Table 2 Structural Properties of Two DOF Structure Used in PSD Tests with T.Modification

\begin{tabular}{|c|c|c|c|c|}
\hline \multirow{2}{*}{\multicolumn{3}{|c|}{$\begin{array}{c}\text { Mass } \\
\left(\mathrm{kg} \cdot \mathrm{sec}^{2} / \mathrm{cm}\right)\end{array}$}} & \multicolumn{2}{|c|}{$\begin{array}{c}\text { Stiffness Matrix } \\
(\mathrm{kg} / \mathrm{cm})\end{array}$} \\
\hline & & & \multirow{2}{*}{$\frac{2 F}{52,280}$} & \multirow{2}{*}{$\frac{\text { If }}{-63,840}$} \\
\hline $2 F$ & \multicolumn{2}{|c|}{85.0} & & \\
\hline IF & \multicolumn{2}{|c|}{85.0} & $-63,840$ & 126,900 \\
\hline \multicolumn{3}{|c|}{ Vibrational Mode } & \multirow{2}{*}{$\begin{array}{l}\text { Natural } \\
\text { Frequency } \\
\left(H_{2}\right)\end{array}$} & \multirow{2}{*}{$\begin{array}{c}\text { Damping } \\
\text { Ratio } \\
(\xi)\end{array}$} \\
\hline & lf & $2 F$ & & \\
\hline 1st & 1.000 & 1.736 & 2.19 & 2.0 \\
\hline 2nd & 1.000 & -0.576 & 6.99 & 5.0 \\
\hline
\end{tabular}

Table 3 Designation and Test Conditions for PSD Tests with T-Modification

\begin{tabular}{|l|l|c|c|}
\hline $\begin{array}{c}\text { Designation } \\
\text { of Test }\end{array}$ & Loading Condition & $\begin{array}{c}\text { Error } \\
\text { Bound } \\
(\mathrm{mm})\end{array}$ & T-Modification \\
\hline \hline EQ03T & Elastic Response & 0.03 & No \\
EQ15T & Elastic Response & 0.15 & No \\
EQ03TM & Elastic Response & 0.03 & Yes \\
EQ15TM & Elastic Response & 0.15 & Yes \\
EQ03PTM & Inelastic Response & 0.03 & Yes \\
ST03TM & Quasi-Static & 0.03 & Yes \\
\hline * As input accelerations, part of the accelerations \\
recorded at Tohoku Univ. during the 1978 Miyagi-oki \\
Earthquake, with the maximum acceleration scaled. \\
\hline
\end{tabular}
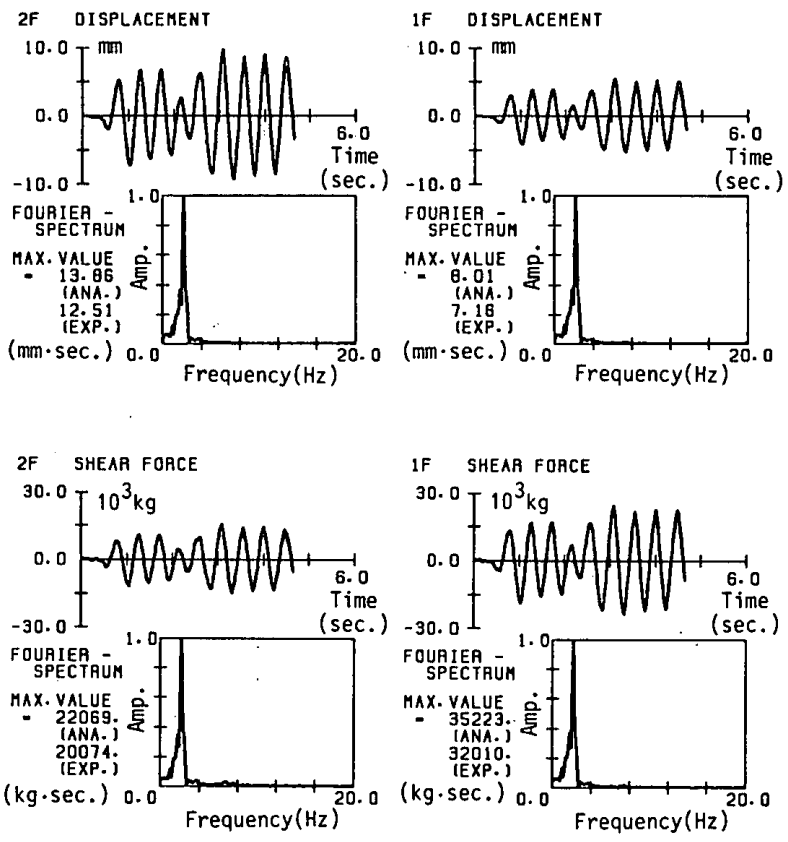

ANALISIS

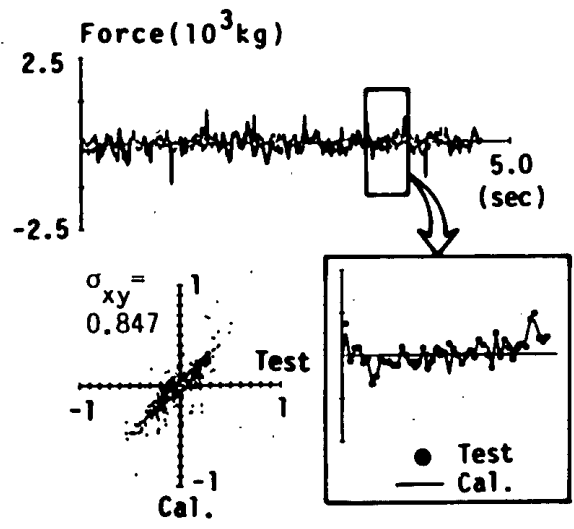

(a) Second Story

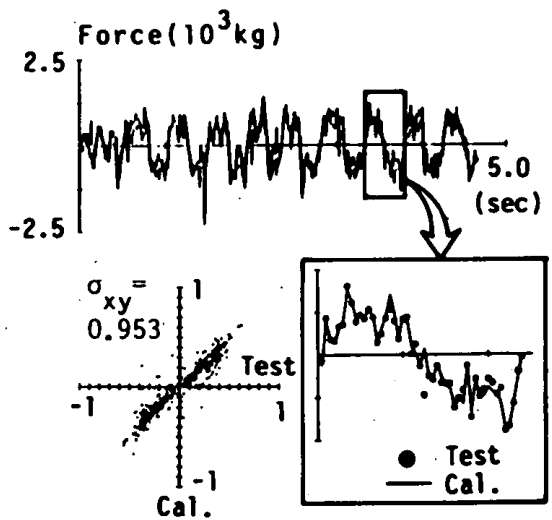

(b) First Story

Fig. 15 Correlation Between Corrected Forces and Forces to be Corrected (Test EQ15TM)

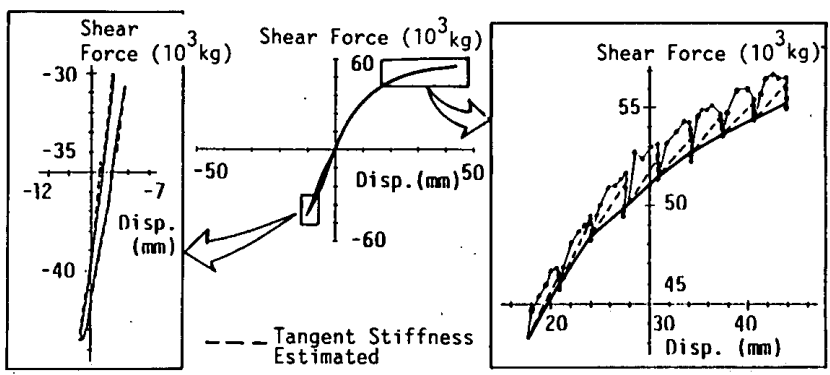

Fig. 16 Correlation Between Estimated and Experimental Stiffnesses (Test ST03TM)

Fig. 14 Time Histories and Fourier Spectra Obtained in Test EQ15TM 
matrix $[k]$ used in the force modification (Equation 10), the tangent stiffness matrix between the present and next steps was used, and the procedure to estimate the tangent stiffness matrix followed ; 1 ) in each time step, the test structure was loaded in accordance with the standard procedure of loading ; 2) during the loading, the force and displacement values were measured continually every after a small time interval as shown in Fig. $12(\mathrm{a})$ and ; 3) using the data collected, the tangent stiffness was estimated using the least square method (Fig. 12(b)). To verify the validity of this algorithm, a two DOF structure shown in Fig. 13 was tested. Tables 2 and 3 list the vibrational properties of the structure and the test program. Figure 14 shows the results obtained from Test EQ15TM (in which the structure responded elastically), demonstrating that the response obtained was very accurate, and thus the algorithm effective (The response of Test EQ15T, in which T-Modification was not employed, diverged quickly). Figure 15 illustrates the forces corrected in this test:i.e. the estimated tangent stiffness matrix times the displacement errors. Correlation between the corrected forces and the forces that should have been be corrected : i. e. the elastic stiffness times the displacement errors, was found excellent, verifying that the tangent stiffnesses estimated were accurate. Figure 16 illustrates closer looks of the estimated tangent stiffnesses against the story shear force versus deflection curves obtained from Test ST03TM. In this test, displacements were applied quasi-statically to the structure, and the tangent stiffnesses were estimated for each small incremental loading by using the algorithm devised. When the structure behaved linearly, the estimated stiffnesses (dashed lines) matched the experimental stiffnesses, but, in the inelastic range, they were constantly larger than the corresponding experimental stiffnesses. This overestimate was believed to have been caused because the restoring forces measured during the loading were larger than the forces measured when the actuator motion was stopped, and this has to do with the effect of loading rate on the restoring forces.

3.3 Values of Algorithms Devised

Comments regarding the values of the algorithms proposed follow. The absolute prerequisite for applying either Ior T-Modification is that the displacement that can be measured in the test is significantly accurate relative to the displacement that can be controlled. It is so because, if this condition does not meet, the displacement error and eventually the force to be modified cannot be estimated correctly. This limitation, however, does not seem to impair the applicability of these algorithms. The PSD test after all is a test with displacement control, and, therefore, no matter what procedures are employed, we cannot ensure reliable results if the test requires control beyond the measurable displacement. T-Modification is to provide more accurate results than I-Modification, because it takes into account the change in stiffness during the nonlinear response, but this algorithm requires additional hardware capacity in order to continually measure and collect the forces and displacements during the loading. On the other hand, I-Modification is simpler and perfectly adaptable to the basic loading procedure developed for the PS.D test. If we are reminded that the error effect normally decreases during the inelastic response, I-Modification is believed still effective for most of practical purposes.

\section{Conclusion}

The major findings obtained from this study follow:

1. The reason why, in the displacement error condition, the highest mode vibration was more promoted was verified.

2. Relationship between the magnitude of displacement errors and the growth of experimental errors was quantified.

3. Algorithms to suppress the experimental error growth were devised, and their effectiveness was demonstrated by PSD tests.

\section{ACKNOWLEDGMENT}

The writers wish to express their gratitude to Drs. S. Okamoto and Y. Yamazaki, Building Research Institute, Ministry of Construction, for their continuous encouragement and valuable comments throughout the study presented.

\section{References}

1) Takanashi, K., et al., "Seismic Failure Analysis of Structures by Computer-Pulsator On-Line System", Journal of the 
Institute of Industrial Science, University of Tokyo, Vol.26, No.11, pp.13-25, December 1974 (in Japanese).

2) Mahin, S. A. and Shing, P. B., "Pseudodynamic Method for Seismic Testing", Journal of the Structural Engineering, ASCE, Vol.111, No.7, pp. 1482-1503, July 1985.

3) Takanashi, K. and Nakashima, M., "Japanese Activities on On-Line Testing”, Journal of the Engineering Mechanics, ASCE, Vol.113, No.7, pp. 1014-1032, July 1987.

4) Nakashima, M. and Kato, H., "Part 3 : Experimental Error Growth in Pseudo Dynamic Testing”, Journal of Structural and Construction Engineering, Transactions of AIJ, No.386, pp.36-48, April 1988.

5) Shing, P.B. and Mahin, S.A. "Experimental Error Propagation in Pseudodynamic Testing", UCB/EERC-83/12, Earthquake Engineering Research Center, University of California, Berkeley, June 1983.

6) Nakashima, M., "Part 1: Relationship Between Integration Time Interval and Response Stability in Pseudo Dynamic Testing”, Journal of Structural and Construction Engineering, Transactions of AIJ, No. 353, pp. 29-36, July 1985.

7) Yamanouchi, H., et al., "Full-Scale Seismic Tests on a Six-Story Concentrically K-Braced Steel Building-US-Japan Cooperative Research Program-", Proceedings of the Fifth Engineering Mechanics Division Specialty Conference, pp. 603-606, August 1984.

8) Seki, M., et al., "Study on Earthquake Response of Two-Stories Steel Frames with Y-Shaped Brace",-Journal of Structural Engineering, Vol. 33 B, pp. 259-271, March 1987 (in Japanese).

9) Yamazaki, Y.; et al., "Accuracy Evaluation of Pseudo Dynamic Response, Earthquake Response Simulation Capacity of Pseudo Dynamic Testing”, Journal of Structural and Construction Engineering, Transactions of AIJ, No. 370, pp. 40-49, December 1986 (in Japanese).

【論 文】

UDC : 624. 042. $7: 620.1$

\section{Part 4 ：仮動的実験における実験誤差の制御 （仮動的実験応答の安定と精度）（梗概）}

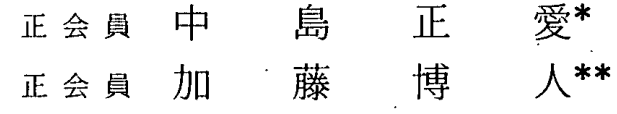

\section{1. 序}

仮動的実験では，加力装置や計測装置の精度が十分で ないと，得られた応答が真の応答から大きくずれてしま う傾向（実験誤差と呼ぶ）がある。筆者らは文献 4）に おいて，この実験誤差の特性を実験的に調べ，1）変位 誤差（目標とする変位（計算変位）と加力後実際に到達 しえた変位（計測変位）の差）が実験誤差に最も大きな 影響を及ぼす誤差因子であること，2）変位誤差はア.ン ダーシュート（計測変位が計算変位によりその増分の絶 対值において小さい現象)という性質を持ちゃすいこと， 3）多自由度系に対する仮動的実験においては，変位誤 差は系の最高次のモードを励起する傾向にあること，を 明らかにした。本論では，変位誤差による実験誤差の特 性を解析的に定量化し，また奏験誤差の累積を抑制する 手順を提案する。

* 神戸大学 助教授・Ph. D.

** 建設省建築研究所 研究員 (1989 年 2 月 9 日原稿受理, 1989 年 5 月 8 日採用決定)

\section{2. 変位誤差の応答に及ぼす影響}

線形 1 自由度系においては, 実験誤差は, 変位誤差と 剛性の積として表される誤差力による系の応答と解釈で きる（式 1$) 。$

\section{1 ランダムな変位誤差の影響}

Shing と Mahinによる詳細な検討（文献 5) を参考 にして，ランダムな変位誤差を含む仮動的実験における

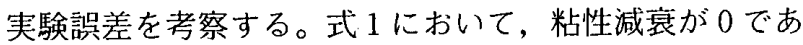
りまた地動加速度がないとし（誤差力だけが作用する状 態)，さらに変位誤差が正規分布に従い，またその平均 值が 0 で標準偏差が $\sigma_{e}$ であるとすると，実験誤差の平 均值は 0 となり，その標準偏差 $\left(\sigma_{r}\right)$ は式 3 で表される。 この関係を図一1に示す。図一1によると，積分時間刻 み $(\Delta t)$ が大きくなるほど実験誤差も大きくなる。多自 由度系では, 高次モ一ドほど相対的な積分時間刻み $(\omega \Delta t)$ が大きいので, 高次モードの応答がより励起され やすいことが分かる。

2.2 アンダーシュートの特性 
線形 1 自由度系に大きさが一定なアンダーシュート

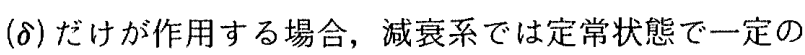
振幅を持つ応答になる (図一2(b), (c))。定常状態での 誤差力は応答と 90 度の位相のずれを持つ矩形波となり， また応答の周期は系の固有周期と一致する。線形 1 自由 度系が矩形波外力を受けたときの応答を（図一 $3(\mathrm{a})$ ) 定 常状態における振幅と矩形波外力の周期の関係として図 -3(b) に示す。この図から, 矩形波の周期が系の固有 周期より短くなると $\left(T / T_{e}<1\right)$, 応答はほとんじ励起 されない。多自由度系で, アンダーシュートによって最 高次のモードが励起していると仮定すると, 図一3(b) の $T / T_{e}$ は最高次の固有周期に対して 1 となり, 他の 低次のモードについてはすべて $T / T_{e}<1$ となる。この 領域では応答はほとんど励起されないので, アンダー シュートによって最高次のモードが卓越すると考えるこ とに不都合はない。

\section{3 アンダーシュートによる実験誤差}

エネルギー的考察によると, 線形 1 自由度系の半サイ クルにおける振幅の変化（図一4）に対して, 式 8 のよ うな漸化式が成立する。この漸化式から求めた振幅の増 幅之時間の関係を図 6 に示す。図一6 と図一1を比べる ことから，系の粘性诚衰があまり大きくなく，また積分 時間刻みが十分に小さいときには，アンダーシュートに よる誤差の累積の方が，ランダムな変位誤差による誤差 の累積よりもはるかに顕著であることが分かる。

\section{4 実験誤差の累積に関する補足事項}

今までの議論では変位誤差の大きさを一定と考えてき た。実験中に現れるもっとも大きな変位誤差を用いて図 -1 , 図一6 を評価すれば, 実験誤差の上限が求められる。 また系が非線形になると相対的な誤差力は小さくなるの で，系が線形であると仮定して求めた実験誤差も，同様 実験誤差の上限値を与える。

\section{3. 実呀誤差の制御}

\section{1 実験誤差の制御之粘性減衰}

系に意図的に大きな粘性減衰を付与して, 実験誤差の 累積を抑制することが考えられる。しかし，多自由度系 において, 変位誤差による高次モードの励起を㧕えるた めに，高次モードにだけ大きな粘性減衰が付与されるよ うな粘性減衰マトリクスを用いると，系が非線形領域に 入り各モードの連成が始まったときに，重要な低次モ一 ドの粘性减衰特性が大きく変わってしまう。またアン ダーシュートは負のクーロン減衰であり，この負の減衰 を一定の粘性減衰比で消去することはできない。粘性減 衰で実験誤差を抑制しようとすると，系の忘答時の粘性 減衰効果が分からなくなる欠点がある。

3.2 実験誤差の累積を制御するアルゴリズム
実験誤差の累積を制御するアルゴリズムを提案する。 実験から得られた復元力を式 10 の乎順で補正し, 補正 した復元力を運動方程式の中に組み入れる。また式 10 の剛性マトリクス $[k]$ として, 初期弾性㓮性マトリクス を用いる(I-Modification)。もし柔が弾性的に挙動す るなら，式 10 は目標とした計算変位に対応する復元力 を与えるはずである。2 自由度系に対する仮動的実験の 結果を図一7〜11に示す。本来なら応答が発散したり, また 2 次のモードが卓越する場合でも，このアルゴリズ ムを適用することによって精度の良い応答が得られた。 図一11 はこのアルゴリズムを用いた弾塑性応答実験結 果である。この補正法では, 系の判性が劣化した非弾性 域でも弾性マトリクスを用いて補正しているので, 補正 によっても誤差が生じるはずであるが, 応答結果は解析 結果に良く一致している。これは非弾性域では履歴によ る堿衰が圧倒的に大きく，わずかな補正誤差による影響 が隠れてしまったものである。非弾性域における補正を より合理的にするために, 式 10 における $[k]$ として, 各ステップ間の接線剛性を用いる手順も洘案した（TModification)。各ステップの加力途中で測った変位と 復元力を用いて接線剛性を求めた(図一12)。図一13に 示す構造物に対して仮動的実験を実施したところ, 補正 を施さないと応答が発散する場合でも，このアルゴリズ ムを用いると安定で精度の良い応答が得られた（図一 14)。得られた接線剛性亡真の剛性とを, 補正すべき復 元力として比べた結果（図一15）, 系が弾性的に応答す る場合には正しく接線剛性が推定できていた。大きな塑 性変形を受けた領域では，推定された剛性が実際の剛性 より高い傾向にあったが(図一16)，これは加力中に測っ た復元力が加力を中断したときに測れる復元力よりも若 干大きかったことが原因であり，またこの違いは復元力 特性に及ぼす載荷速度の影響に起因している。

\section{3 提案アルゴリズムの適用度}

ここで提案したアルゴリズムを用いるためには, 計測 できる変位が制御できる変位に比へてて十分に小さいこと が必要である。しかし，仮動的実験の本質が変位制御実 験であり，したがって計測できる変位よりも小さい変位 を制御することが要求される場合には，しょせん正しい 応答が期待できないことを考えると，この制約が提案し たアルゴリズムの適用度を減ずるとは考えられない。

\section{4. 結 論}

(1) 変位誤差が系の最高次のモードの忘答を励起し やすいことを証明した。（2）変位誤差し実験誤差の累 積の関係を定量化した。（3）実験誤差の累積を制御し ながら実験を進める手順を提案し，その妥当性を実際の 仮動的実験によって確かめた。 